\title{
OPTIMALISASI PEMBIAYAAN PADA SEKTOR PRODUKTIF MIKRO DI BANK BTPN SYARIAH
}

\author{
Trimulato \\ Prodi Perbankan Syariah Universitas Islam Negeri Alauddin Makassar \\ $\square_{e-m a i l}$ : trimsiuii@yahoo.co.id
}

\begin{abstract}
Sharia banking has a role as an institution that collects funds from the society and disburses funds in the form of financing. Sharia banking exceeded market share more 5 percent. The growth experienced by sharia banking. The activities of financing at sharia banking are still dominated by by 42.80 percent or 123,178,000,000,000 for consumtion. Financing for consumtion is bigger compared capital of working and investment. Bank BTPN Syariah is a sharia banking focuses only financing for productive activities of micro. This research is qualitative, the purpose know the growth of financing distribution BTPN Syariah and competitive cost pattern. Results of this study indicates the growth of financing distribution in BTPN Syariah in June 2017 and June 2018 grew by 18.128 percent. Financing distribution model given by BTPN Syariah is only for micro project activities. Financing is called the Future Packaging (PMD), only for womens collapsed, and not possible goods collateral.
\end{abstract}

Keywords: Financing, Productive Micro Sector, and Bank BTPN Syariah.

\begin{abstract}
Abstrak
Perbankan syariah memiliki peran sebagai lembaga yang menghimpun dana dari masyarakat dan menyalurkan dana dalam bentuk pembiayaan. Pangsa pasar bank syariah menembus 5 persen. Pertumbuhan dialami bank syariah. Pembiayaan kegiatan konsumtif masih menjadi dominasi di bank syariah sebesar 42,80 persen atau sebesar 123.178.000.000.000. Pembiayaan konsumtif lebih besar jika dibandingkan pembiayaan untuk modal kerja dan investasi. Bank BTPN Syariah merupakan bank syariah yang fokus hanya menyalurkan pembiayaan untuk kegiatan produktif sektor mikro. Penelitian ini bersifat kualitatif, tujuan untuk mengetahui pertumbuhan penyaluran pembiayaan di Bank BTPN Syariah serta pola pembiayaan sektor produktif mikro yang dilakukannya. Dari hasil penelitian ini menunjukkan bahwa pertumbuhan penyaluran pembiayaan di Bank BTPN Syariah pada periode Juni 207 dan Juni 2018 tumbuh sebesar 18,128 persen. Model penyaluran pembiayaan yang diberikan bank BTPN Syariah hanya untuk kegiatan produktif mikro. Pembiayaan itu disebut Paket Masa Depan (PMD), hanya diperuntuhkan untuk kalangan peremuan prasejahterah, serta tidak memberikan kewajiban untuk penyertaan jaminan.
\end{abstract}

Kata Kunci: Pembiayaan, Sektor Produktif Mikro, dan Bank BTPN Syariah. 


\section{Pendahuluan}

Ekonomi Islam didefenisikan sebagai cabang ilmu yang membantu merealisasikan kesejahteraan manusia melalui alokasi dan distribusi sumber daya yang langka, yang sejalan dengan ajaran Islam, tanpa membatasi kebebasan individu ataupun menciptakan ketidakseimbangan makro dan ekologis. Disamping itu ekonomi islam sebagai aplikasi petunjuk dan aturan syariah yang mencegah ketidakadilan dalam memperoleh dan menggunakan sumber daya material agar memenuhi kebutuhan manusia dan agar menjalankan kewajibannya kepada Allah dan masyarakat (Sholahuddin, 2007). Semua orang diperlakukan sama dalam memperoleh kesempatan, tidak ada perbedaan antarindividu atau kelompok atau kelas dalam masyarakat. Setiap individu harus mendapatkan kesempatan yang sama untuk hidup secara layak, belajar, bekerja, bekerja, jaminan keamanan, jaminan kesehatan, dan kesempatan pemenuhan hakhak kemanusiaan lainnya. Kesejahteraan dan hasil pembangunan didistribusikan harus kepada setiap orang dan tidak mengumpul pada kelompok tertentu (P3EI UII, 2008).

Salah satu kelompok pejuang ekonomi negeri Indoneia adalah kelompok UKM. Kemampuan UMKM dalam menghadapi terpaan arus persaingan global memang perlu dipikirkan lebih lanjut agar tetap mampu bertahan demi kestabilan perekonomian Indonesia. Selain itu faktor sumber daya manusia di dalamnya juga memiliki andil tersendiri. Strategi pengembangan UMKM untuk tetap bertahan dapat dilakukan dengan peningkatan daya saing dan pengembangan sumber daya manusianya agar memiliki nilai dan mampu bertahan menghadapi pasar ACFTA, diantaranya melalui penyaluran perkreditan (KUR), penyediaan akses informasi pemasaran, pelatihan lembaga keuangan mikro melalui capacity building, dan pengembangan information technology (IT) (kemenkeu.go.id).
Konsultan ekonomi syariah sekaligus Managing Director at Rasyidin Consulting Wiku Suryomurti mengatakan, dalam beberapa tahun ini perbankan syariah terus gencar menyalurkan dana bagi para pelaku UMKM. Pada satu sisi pencapai target pangsa pasar 5\% memang belum tercapai (hanya 4,8\%), tapi di sektor pembiayaan UMKM kinerja bank-bank syariah mulai maksimal. Di Indonesia, ada sekitar 52 juta UMKM yang eksis hingga hari ini. Sayangnya, keberadaan mereka belum banyak terakomodasi permodalan oleh bankbank besar. Sebagian perbankan besar masih khawatir terhadap keberlanjutan UMKM tersebut. Sementara itu, kata Wiku, dalam hal ini perbankan syariah lebih mengakomodasi mereka. Pasalnya, sistem perbankan syariah lebih minimalis tingkat pengaruhnya terhadap gejolak ekonomi (bankmuamalat.co.id).

Bukan hanya lembaga komersil seperti bank yang berkontribusi dalam sektor riil lembaga ekonomi Islam yang bersifat sosial juga gencar menggerakkan sektor riil umkm. Pemberian modal usaha dalam bentuk pinjaman atau hibah di sektor UKM (Usaha Kecil dan Menengah) telah banyak dilakukan, baik oleh pemerintah secara langsung maupun melalui fasilitas perbankan. Tetapi belum banyak program bantuan modal bagi UKM yang dipadukan dengan pembinaan mental dan agama. Program semacam itu masih jarang, tapi bagi lembaga zakat merupakan sesuatu yang tidak asing lagi. BAZNAS pekan lalu menggulirkan bantuan modal bagi pedagang kaki lima melalui program kerjasama CSR BRI Syariah. Para calon penerima bantuan modal wajib mengikuti pelatihan fikih muamalat, seperti materi jual beli dalam Islam dan sebagainya, sebagai salah satu bentuk pembinaan mental dan agama yang melekat di dalam misi lembaga zakat. Pembinaan mental dan agama sangat penting dalam pembangunan ekonomi, termasuk pemberdayaan UKM, sebagai sarana untuk mewujudkan masyarakat yang produktif (baznas.go.id). 
Direktur Eksekutif Dompet Dhuafa Yuli Pujihardi, menambahkan setiap tim divisi ekonomi Dompet Dhuafa ingin mengembangkan perekonomian suatu daerah, maka tim akan melihat lebih dalam potensi lokal yang ada, sehingga dapat diangkat menjadi ikon daerah tersebut. "Dengan melihat potensi lokal yang ada sudah terbukti Dompet Dhuafa semakin mudah dalam memberdayakan masyarakat. Karena itu semua seuai kultur jadi tak perlu mengubah apa yang ada, tinggal meneruskan menjadi semakin baik saja," jelas Yuli. Dompet Dhuafa memberikan pembinaan kepada binaan UMKM selama dua tahun, kemudian diharapkan binaan bisa mandiri dan tak tergantung lagi pada pendampingan dari Dompet Dhuafa (mysharing.co.id).

Bank syariah yang sejatinya melekat pada identitasnya sebagai lembaga keuangan syariah yang akan mendukung pertumbuhan sektor riil khususnya pada kegiatan ekonomi produktif belum menjadikan porsi pembiayaan pada kegiatan produktif. Sebagaimana data berikut;

\section{Tabel 1.1}

\section{Porsi Pembiayaan di Bank Syariah Periode April 2018}

\begin{tabular}{|c|c|c|c|}
\hline NO & $\begin{array}{c}\text { TUJUAN } \\
\text { PEMBIAYAA } \\
\text { N }\end{array}$ & $\begin{array}{c}\text { BESAR } \\
\text { PEMBIAY } \\
\text { AAN }\end{array}$ & $\begin{array}{c}\text { PORSI } \\
\text { PEMBIAYAA } \\
\mathbf{N}\end{array}$ \\
\hline 1 & $\begin{array}{c}\text { Modal } \\
\text { Kerja }\end{array}$ & 97.569 & $33,91 \%$ \\
\hline 2 & Investasi & 67.008 & $23,29 \%$ \\
\hline 3 & Konsumsi & 123.178 & $42,80 \%$ \\
\hline $\mathbf{4}$ & Jumlah & $\mathbf{2 8 7 . 7 5 5}$ & $\mathbf{1 0 0} \%$ \\
\hline
\end{tabular}

Sumber: Statistik Perbankan Syariah (OJK,2018)/ Data diolah Rupiah

Dari data diatas menunjukkan bahwa penyaluran pembiayaan di bank syariah pada periode April Tahun 2018 masih didominasi untuk pembiayaan untuk keperluan konsumtif yaitu sebesar 42,80 persen atau sebesar 123.178.000.000.000. Lalu porsi kedua yaitu penyaluran pembiayaan modal kerja sebesar 33,91 persen, dan terakhir porsi untuk penyaluran pembiayaan pada investasi sebesar 23,29 persen. Perlu ada kesunggguhan dari perbankan syariah untuk bisa mendukung sektor rill khususnya kegiatan produktif mikro kecil dan menengah. Untuk menjaga konsistensinya sebagai lembaga yang akan menopang dan berkontribusi bagi negara.

Saat ini telah hadir perbankan syariah yang konsen untuk memberikan pembiayaan pada kegiatan sektor produktif mikro yaitu Bank BTPN syariah.

Bank BTPN Syariah berkomitmen untk memberikan pembiayaan pada sektor produktif mikro. Bank BTPN Syariah fokus membangun ekonomi umat melalui pemberdayaan perempuan. Segmen penyaluran pembiayaannya pun menyasar para pelaku super mikro atau masyarakat prasejahtera produktif. Direktur Utama BTPN Syariah Ratih Rachmawaty menyatakan, bila ibu berdaya maka keluarga juga ikut berdaya. "Visi kami menjadi bank syariah terbaik untuk keuangan inklusif dan mengubah hidup berjuta rakyat Indonesia," ujarnya kepada wartawan di Bandung. Ia menjelaskan, setiap nasabah super mikro bisa mendapatkan pembiayaan Rp 2 juta per orang. Skema peminjamannya pun cukup mudah karena, bank tidak meminta jaminan apa pun. "Jaminannya hanya muka. Selama mukanya terus bertemu dengan karyawan kami ya kami sudah senang membuat mereka jadi nasabah kami. Kami nggak tanya, punya STNK motor atau sertifikat rumah atau nggak, " kata Ratih. Menurutnya, BTPN Syariah tidak perlu menanyakan jaminan sebab yang disasar memang masyarakat unbankable. "Kalau punya sertifikat seperti itu berarti bankable, bagi kami selama mau usaha, mari kita layani," ujarnya. Ia menyebutkan, berdasarkan penelitian Kuantatif Synovate pada 2008, sebanyak 71 persen orang belum pernah meminjam dari bank. Sebanyak 34 persen mengaku tidak meminjam di bank karena prosesnya rumit, lalu 28 persen lainnya mengaku tidak punya uang. Maka dari itu, BTPN Syariah berusaha mempermudah nasabah unbankable di seluruh Indonesia 
untuk mendapatkan pembiayaan. Dari uraian diatas penulis merasa tertarik untuk melakukan pendalaman mengenai model pembiayaan di bank syariah khususnya yang telah dilakukan oleh bank BTPN syariah yang konsen memberikan pembiayaan untuk kegiatan sektor produktif mikro. Adapun yang menjadi fokus dari tulisan/penelitian ini yaitu produk pembiayaan Bank BTPN Syariah serta model penyaluran pembiayaan mikro bank BTPN Syariah.

\section{Rumusan Masalah}

1) Bagaimana pertumbuhan pembiayaan di Bank BTPN Syariah ?

2) Bagaimana Model Pembiayaan kegiatan Produktif Mikro di Bank BTPN Syariah ?

\section{Tujuan Penelitian}

1) Untuk mengetahui pertumbuhan pembiayaan di Bank BTPN Syariah?

2) Untuk mengetahui model penyaluran pembiayaan kegiatan produktif mikro di Bank BTPN Syariah?

\section{Landasan Teori}

Pembiayaan di Bank Syariah

Pembiayaan merupakan salah satu tugas pokok bank, yaitu pemberian fasilitas penyediaan dana untuk memenuhi kebutuhan pihak-pihak yang merupakan defisit unit. Menurut sifat penggunaannya, pembiayaan dapat dibagi menjadi (Nurkholis, 2008):

- Pembiayaan konsumtif, yaitu pembiayaan yang digunakan untuk memenuhi kebutuhan konsumsi, yang akan habis digunakan untuk dipakai memenuhi kebutuhan.

- Pembiayaan produktif, yaitu pembiayaan yang ditujukan untuk memenuhi kebutuhan produksi dalam arti luas, yaitu untuk peningkatan usaha, baik usaha produksi, perdagangan, maupun investasi.

Menurut keperluannya, pembiayaan produktif dapat dibagi menjadi; a. Pembiayaan modal kerja, yaitu pembiayaan untuk memenuhi kebutuhan (1) peningkatan produksi, baik secara kuantitatif, yaitu jumlah hasil produksi, maupun secara kualitatif, yaitu peningkatan kualitas atau mutu hasil produksi; dan (2) untuk keperluan perdagangan atau peningkatan utility of place dari suatu barang.

b. Pembiayaan investasi, yaitu untuk memenuhi kebutuhan barang-barang modal (capital goods) serta fasilitasfasilitas yang erat kaitannya dengan itu. Secara umum jenis-jenis pembiayaan dapat digambarkan sebagai beriku (Nurkholis, 2008);

1. Konsumsi

2. Produktif

a. Modal Kerja

b. Investasi

\section{Usaha Mikro Kecil dan Menengah (UMKM)}

Usaha mikro merupakan usaha yang dikelola oleh individu atau keluarga atau beberapa orang yang belum memiliki izin usaha secara lengkap (Alim.2009). Dalam UU No. 20 tahun 2008 tentang UMKM bahwa unit usaha mikro adalah usaha produktif yang dimiliki orang per orang dan/atau badan usaha perorangan yang memenuhi kriteria usaha mikro sebagaimana yang diatur dalam udang-undang (UU No. 20 tahun 2008). Pengertian lain dikemukakan Warkum Sumitro, usaha mikro kecil dan menengah adalah usaha yang dilakukan oleh suatu perusahaan dengan tenaga kerja yang digunakan tidak melebihi dari 50 orang (Sumitro, 2004).

\section{Ekonomi Islam dan Sektor Riil UMKM}

Dalam ekonomi islam yang menjadi penopang atau tombak perekonomian suatu Negara adalah sektor riil. Sedangakan sektor moneter menjadi faktor pendukung dalam menciptakan perkembangan dari sektor riil itu sendiri. Dengan adanya sektor keuangan khususnya semakin banyaknya Lembaga Keuangan Syariah sebagaimana fungsinya 
menghimpun dana (funding) dari masyarakat yang kemudian disalurkan dalam bentuk pembiayaan (financing) terhadap berbagai jenis usaha. Perkembangan sektor rill dengan baik secara tidak langsung akan menciptakan lapangan kerja, sebab tenaga kerja yang diserap akan semakin banyak. Dinyatakan juga bahwa keunggulan sistem syariah itu kebal dari krisis, bahkan bisa menjadi solusi dari krisis. Karena system syariah tidak melepaskan diri dari underlaying transactions. Padahal, kegiatan ekonomi yang riil tidak bisa mengandalkan pendanaan yang bersifat spekulatif

(Majalah Sharing.2009).

\section{Metode Penelitian}

Jenis penelitian yang digunakan dalam tulisan ini adalah dengan menggunakan studi pustaka yang diperoleh dari beberapa sumber. Baik dari data yang telah disajikan dan melalui beberapa media yang relevan dengan tema dalam tulisan ini,meliputi tentang pembiayaan di bank syariah.

Penelitian ini bersifat deskriptif kualitatif yang artinya menggambarkan suatu subyek penelitian. Dalam hal ini adalah terkait dengan pembiayaan di bank syariah, khusus mengenai pertumbuhan pembiayaan yang disalurkan oleh Bank BTPN Syariah. Serta model penyaluran pembiayaan untuk kegiatan sektor produktif mikro yang dilakukan di Bank BTPN Syariah.

Jenis data yang digunakan dalam tulisan ini adalah data kualitatif yang bersumber dari data primer dan data sekunder. Data primer berupa sumber data yang langsung memberikan data kepada peneliti atau data yang diperoleh langsung dari lapangan (objek penelitian), sedangkan data sekunder adalah sumber data yang tidak langsung memberikan data kepada pengumpul data (peneliti) atau data yang diambil peneliti sebagai pendukung atas penelitian secara ilmiah yaitu dengan melakukan studi pustaka (penelusuran melalui buku, artikel, jurnal, majalah, internet dan sumber lainnya).
Data-data yang digunakan penulis antara lain:

1. Teori-teori yang peneliti ambil dari berbagai literatur.

2. Pengambilan data-data dari hasil yang telah tersaji dari suatu lembaga.

Batasan dalam tulisan ini difokuskan pada perkembangan pembiayaan yang ada di Bank BTPN Syariah khususnya sampai tahun 2018, serta pola desain dari model penyaluran pembiayaan kegiatan sektor produktif mikro yang selama ini dilakukan di Bank BTPN Syariah.

Teknik pengumpulan data yang diperlukan dalam tulisan ini adalah dengan menggunakan beberapa metode yaitu:

\section{1) Studi Kepustakaan}

Metode ini digunakan untuk menggali dasar-dasar teori yang terkait dengan produk pembiayaan di bank syariah, serta terkait dengan ekonomi mikro, terkait lembaga keuangan Islam, serta peran lembaga keuangan syariah khususnya perbankan syariah dalam mendukung sektor riil khususnya pada UMKM.

\section{2) Pengamatan}

Setiap data yang didapatkan dari berbagai sumber diamati dan dianalisa terkait dengan kondisi pertumbuhan dari pembiayaan yang disalurakan bank BTPN Syariah sampai tahun 2018. Serta terkait model dari penyaluran pembiayaan yang dilakukan oleh bank BTPN Syariah untuk sektor produktif mikro.

Metode analisis data yang digunakan adalah dengan menggunakan pendekatan kualitatif deskriptif yaitu dengan cara memaparkan perkembangan dari pembiayaan yang disalurkan oleh Bank BTPN Syariah, serta menguraikan model pembiayaan yang diberikan oleh Bank BTPN Syariah, sebagai pembiayaan yang difokuskan hanya untuk kegiatan sektor produktif mikro.

Penelitian kualitatif adalah prosedur penelitian yang menghasilkan data deskriptif berupa kata-kata tertulis atau lisan dari orang-orang dan keadaan yang diamati. 
Penelitian kualitatif adalah metode penelitian yang digunakan untuk meneliti pada kondisi objek yang alamiah, (sebagai lawannya adalah eksprimen) dimana peneliti adalah sebagai instrument kunci, teknik pengumpulan data dilakukan secara trianggulasi (gabungan), analisa data bersifat induktif dan hasil dari penelitian kualitatif lebih bersifat makna daripada generalisasi (Farizal, 2010).

\section{Hasil dan Pembahasan}

\section{Perkembangan Pembiayaan di Bank BTPN Syariah}

\section{Tabel 3.1}

Pertumbuhan Pembiayaan di Bank BTPN Syariah Periode Juni 2018

\begin{tabular}{|c|c|c|c|c|}
\hline $\mathbf{N}$ & JENIS \\
$\mathbf{O}$ & $\begin{array}{c}\text { PEMBIA } \\
\text { YAAN }\end{array}$ & $\begin{array}{c}\text { JUNI } \\
\mathbf{2 0 1 7}\end{array}$ & $\begin{array}{c}\text { JUNI } \\
\mathbf{2 0 1 8}\end{array}$ & $\begin{array}{c}\text { PERTUM } \\
\text { BUHAN }\end{array}$ \\
\hline 1 & $\begin{array}{c}\text { Piutang } \\
\text { murabah } \\
\text { ah }\end{array}$ & $\begin{array}{c}7.198 \\
.144\end{array}$ & $\begin{array}{c}8.503 \\
.038\end{array}$ & $18,128 \%$ \\
\hline 2 & $\begin{array}{c}\text { Piutang } \\
\text { istishna }\end{array}$ & - & - & - \\
\hline 3 & $\begin{array}{c}\text { Piutang } \\
\text { qardh }\end{array}$ & 93 & 118 & $26,882 \%$ \\
\hline 4 & $\begin{array}{c}\text { Piutang } \\
\text { sewa }\end{array}$ & - & - & - \\
\hline 5 & $\begin{array}{c}\text { Mudhar } \\
\text { abah }\end{array}$ & - & - & - \\
\hline 6 & $\begin{array}{c}\text { Musyara } \\
\text { kah }\end{array}$ & - & - & - \\
\hline $\mathbf{7}$ & $\begin{array}{c}\text { Jumlah } \\
\mathbf{7 . 1 9 8}\end{array}$ & $\mathbf{8 . 5 0 3}$ & $\mathbf{1 8 , 1 2 8 \%}$ \\
\hline
\end{tabular}

Sumber Laporan Keuangan Bank BTPN Syariah Juni 2017 dan Juni 2018 (Data diolah)

Dari data diatas menunjukkan pertumbuhan pembiayaan yang disalurkan oleh Bank BTPN Syariah pada periode Juni 2017 dan Juni 2018 yang tumbuh sebesar 18,128 persen. Pembiayaan yang disalurkan oleh Bank BTPN Syariah didominasi oleh pembiayaan murabahah sebesar 99,99 persen, sedangkan akad pembiayaan qard hanya 0,01 persen atau hanya sebesar 118 juta pada juni 2018. Bahkan bank BTPN Syariah tidak menggunakan seluruh akad yang berlaku di bank syariah. Akan sangat besar peluang pertumbuhan dialami bank BTPN syariah jika memanfaatkan akadakad yang bisa mendukung kegiatan usahanya. Bank BTPN Syariah yang konsen dan fokus hanya penyalurkan pada pembiayaan sektor produktif mikro dapat memanfaatkan akad yang ada, khususnya akad dengan skema bagi hasil yaitu akad mudharabah dan musyarakah. Kedua akad ini sangat cocok dan relevan bagi pola pembiayaan kegiatan produktif, lebih fair bagi semua pihak.

\section{Optimalisasi Pembiayaan Sektor Produktif Mikro di Bank BTPN Syariah}

BTPN Syariah adalah Bank Umum Syariah ke 12 di Indonesia, memiliki tekad untuk menumbuhkan jutaan rakyat Indonesia sehingga memiliki kehidupan yang lebih baik. Melalui produk dan aktivitasnya, BTPN Syariah senantiasa mengajak dan melibatkan seluruh stakeholders untuk bersama-sama memberikan kemudahan akses masyarakat dalam menggunakan atau memanfaatkan produk dan layanan jasa bank (financial inclusion), memberikan informasi, serta kegiatan pemberdayaan yang berkelanjutan dan terukur. Sebagai bank baru, BTPN Syariah berupaya menyediakan produkproduk unggulan yang mengedepankan pemenuhan kebutuhan nasabah untuk memiliki kehidupan yang lebih baik.

Fokus pada pemberdayaan nasabah prasejahtera produktif, BTPN Syariah memiliki dua produk Utama Pendanaan dan Pembiayaan. Kedua produk tersebut sematamata ditujukan untuk memberdayakan keluarga pra-sejahtera produktif. Pembiayaan "Tidak hanya memberikan akses dan kebutuhan modal usaha (keuangan inklusif), pembiaayaan BTPN Syariah memberikan program pemberdayaan bagi jutaan nasabahnya" Paket Masa Depan (PMD) menjadi produk unggulan kami di program pembiayaan. Seiring dengan pertumbuhan dan kebutuhan nasabah pembiayaan, BTPN Syariah akan terus melahirkan inovasi baru demi memperbaiki kehidupan nasabah dan keluarganya (btpnsyariah.co.id). 
Pinjaman syariah yang ada di Btpn Syariah disebut dengan PMD (Paket Masa Depan), namun pinjaman ini hanya diberikan kepada sekelompok wanita yang ada di pedesaan yang ingin berusahaan dan memiliki impian untuk merubah hidup, tapi tidak punya akses ke layanan perbankan. Program ini mengedepankan 4 prilaku yang mereka miliki untuk menggapai mimpi, prilaku tersebut diantaranya berani berusaha, disiplin, kerja keras dan saling bantu. Secara rutin, bank btpn syariah melakukan program pemberdayaan yang berkelanjutan dan terukur. PMD mencakup empat elemen yakni: memberikan solusi keuangan, perencanaan keuangan sederhana, partisipasi kelompok dan melibatkan karyawan BTPN untuk bertindak sebagai fasilitator dan menjadi teladan bagi nasabah BTPN Syariah (infobank.com).

Pola pembiayaan bank BTPN Syariah disalurkan bagi masyarakat pra sejahterah khususnya perempuan. Untuk produk pembiayaan BTPN Syariah menyediakan program Paket Masa Depan (PMD). PMD merupakan program terpadu BTPN Syariah yang diberikan kepada sekelompok wanita di pedesaaan yang ingin berusaha dan memiliki impian untuk merubah hidup tetapi tidak memiliki akses ke layanan perbankan. PMD menawarkan beberapa manfaat bagi nasabah yang menggunakannya, yaitu: Pembiayaan, Tabungan, dan Manfaat Asuransi. Dengan fasilitas pembiayaan mulai dari $\mathrm{Rp}$ 1.000.000.- hingga Rp 50.000.000,-. Dan pembayaran yang dapat dilakukan dengan cicilan yang dilakukan setiap dua minggu dalam waktu satu tahun (syariahbank.com).

Produk pembiayaan syariah ini memberikan penekanan pada paket pembiayaan untuk tujuan PRODUKTIF. Dan Kami juga percaya bahwa program pemberdayaan yang fokus pada pembangunan karakter yang membentuk kebiasaan-kebiasaan baik merupakan suatu hal yang sangat penting bagi keberhasilan program ini. Oleh karena itu, Paket Masa Depan dirancang untuk membangun empat perilaku utama. Pertama adalah Keberanian memulai bisnis. Kedua adalah Disiplin dalam memegang komitmen untuk tepat waktu dan untuk mengelola dana secara bijaksana. Ketiga adalah Bekerja Keras dalam mengelola dan menumbuhkan bisnis, dan keempat adalah membangun Solidaritas Kelompok dalam kelompok mereka masingmasing. Paket Masa Depan terdiri dari 4 komponen yang saling mengait : Pembiayaan + Tabungan + Asuransi berkelanjutan Pelatihan Daya (Capacity Building Program) Sistem keanggotaan (Kelompok formal, pertemuan wajib dua mingguan,disiplin menabung, tanggung renteng) Karyawan bank terlatih untuk jadi Pembina Paket Masa depan menyediakan pinjaman dengan angsuran 2 mingguan dengan tenor 1 tahun, tanpa jaminan dan memiliki proteksi asuransi Jiwa tanpa biaya dalam masa pembiayaan. Syarat Pembukaan Rekening: Akad Wakalah, Mengikuti Pelatihan yang diberikan oleh Bank. Mengisi Aplikasi Permohonan Pembiayaan dan Pembukaan Rekening Menunjukkan Kartu Identitas/Surat Keterangan Domisili Asli (Fanpagebtpnsyariah).

Kaum perempuan yang menjadi segmen nasabah pilihan BTPN Syariah itu memiliki usaha beragam, seperti konveksi, warung kopi, jualan bakso, warung mi, dan perdagangan dengan sistem daring (online). Sebenarnya segmen nasabah BTPN Syariah adalah masyarakat prasejahtera produktif, namun anak usaha Bank BTPN itu memfokuskan diri kepada nasabah perempuan karena yakin untuk meningkatkan kesejahteraan keluarga maka perempuan atau ibu memainkan peran yang sangat penting. Selain itu, perempuan lebih mudah diajak berdisiplin sehingga risiko pemberian pinjaman dapat ditekan sekecil mungkin (antaranews.com).

Bank BTPN Syariah fokus membangun ekonomi umat melalui pemberdayaan perempuan. Segmen penyaluran pembiayaannya pun menyasar para pelaku super mikro atau masyarakat prasejahtera produktif. Direktur Utama BTPN Syariah Ratih Rachmawaty menyatakan, bila ibu 
berdaya maka keluarga juga ikut berdaya. "Visi menjadi bank syariah terbaik untuk keuangan inklusif dan mengubah hidup berjuta rakyat Indonesia. setiap nasabah super mikro bisa mendapatkan pembiayaan Rp 2 juta per orang. Skema peminjamannya pun cukup mudah karena, bank tidak meminta jaminan apa pun. "Jaminannya hanya muka. Selama mukanya terus bertemu dengan karyawan kami ya kami sudah senang membuat mereka jadi nasabah. BTPN Syariah tidak perlu menanyakan jaminan sebab yang disasar memang masyarakat unbankable. BTPN Syariah berusaha mempermudah nasabah unbankable di seluruh Indonesia untuk mendapatkan pembiayaan. Para nasabah menggunakan pinjaman tersebut untuk menjalankan industri rumah tangga, seperti membuat telur asin, keset dari kain perca, dan lainnya. Nasabah mendapatkan tambahan pembiayaan setelah satu tahun. "Kalau tahun pertama dapat Rp 2 juta, setelah mukanya rutin hadir terus tahun berikutnya mereka boleh dapat maksimum Rp 4 juta,"(republika.co.id).

Inovasi BTPN Syariah dalam Layanan Keuangan Inklusif, BTPN Wow! iB adalah layanan perbankan bagi mass market yang memanfaatkan teknologi telepon genggam dan didukung jasa agen sebagai perpanjangan tangan BTPN Syariah untuk meningkatkan jangkauan layanan kepada nasabah di seluruh pelosok Indonesia (btpnsyariah.com). Agen BTPN Wow dapat sekaligus menjual produk BTPN Syariah. Berdasarkan aturan OJK, agen Laku Pandai dari bank konvensional juga dapat menjual produk anak usaha syariah.Pola penyaluran pembiayaan di Bank BTPN syariah cukup berbeda jika dibandikan dengan pembiayaan di bank-bank syariah lainnya.

Pembiayaan di Bank BTPN Syariah hanya difokuskan untuk kegiatan produktif mikro. Lebih khusus lagi disalurkan hanya untuk kaum perempuan yang prasejahterah. Penyaluran pembiayaan di Bank BTPN Syariah untuk usaha-usaha mikro yang sudah ada dengan plafon pembiayaan yang cukup

kecil. Dalam pembiayaan yang disalurkan bank BTPN Syariah, nasabah tidak dibebankan jaminan untuk mendapatkan bantuan permodalan, hanya saja diwajibkan untuk hadir pertemuan rutin perdua mingguan. Para nasabah akan dibimbing langsung oleh pegawai wanita dari bank BTPN syariah terkait perkembangan bisnis. Nasabah pembiayaan Bank BTPN syariah bisa mendapatkan layanan BTPN Syariah WoW IB, yaitu fasilitas dalam rangka kegiatan keuangan inklusi, akses layanan keuangan melalui handphone.

\section{Kesimpulan}

Pertumbuhan penyaluran pembiayaan di Bank BTPN Syariah pada periode Juni 2017 dan Juni 2018 tumbuh sebesar 18,128 persen. Pembiayaan didominasi oleh pembiayaan murabahah sebesar 99,99 persen atau sebesar 8.503.038.000.000, sedangkan 0,01 persen atau sebesar 118.000.000 untuk pembiayaan dengan akad Qard. Belum semua akad pembiayaan digunakan oleh Bank BTPN Syariah seperti akad salam, istisnha', mudharabah, musyarakah, dan ijarah.

Bentuk penyaluran pembiayaan yang diberikan oleh Bank BTPN Syariah dalam bentuk pembiayaan produktif, tidak melayani pembiayaan konsumtif. Pembiayaan yang disalurkan Bank BTPN Syariah menyalurkan pembiayaan dengan nama Paket Masa Depan (PMD). PMD pembiayaan yang disalurkan diberikan kepada kaum wanita prasejahterah untuk melakukan usaha mikro. PMD tidak mengharuskan nasabah menyertakan barang jaminan, nasabah hanya diminta hadir dalam pertemuan rutin sentra Bank BTPN Syariah. Nasabah bisa mendapatkan tamabahan pembiayaan bagi nasabah yang disiplin. Selain itu nasabah pembiayaan PMD bisa memperoleh layanan Waw IB, yaitu bagian dari kegiatan inklusi keuangan, layanan perbankan syariah dengan memanfaatkan handphone.

\section{REFERENSI}


Abdul, Al-Mishri Sami'. 2006. Pilar-Pilar Ekonomi Islam. Yogyakarta: Penerbit Pustaka Pelajar. H 46.

Algaoud, Latifa M. dan Mervyn K. Lewis. 2001. Perbankan Syariah, Prinsip, Praktik, Prospek. Jakarta: PT. Serambi Ilmu Semesta. H 9-10.

Alim, Nizarul Alim. 2009. Pembiayaan Syari'ah untuk Usaha Mikro dan Kecil: Studi Kasus Dan Solusi, Cet. I. Surabaya: PT. Bina Ilmu. H 14.

Amah, Nik. 2014. Bank Syariah dan UMKM Dalam Menggerakkan Roda Perekonomian Indonesia : Suatu Kajian Literatur, Jurnal Assets : Jurnal Akuntansi dan Pendidikan, Vol 2. No 1. Madiun: Program Studi Pendidikan Akuntansi, FPIPS, IKIP PGRI Madiun. H 53.

Arwati, Dini. 2013. Peran Strategis Ekonomi Berbasis Syariah Dalam Pemberdayaan Ekonomi Sektor Usaha Mikro, Kecil, dan Menengah (UMKM), Ditinjau Dari Penerapan Akuntasi Syariah dan Akuntansi UMKM. Jurnal Ekono-Insentif, Vol 4. No 1. Bandung: Koordinasi Perguruan Tinggi Swasta Wilayah IV Jawa Barat dan Banten. H 12.

Danupranata, Gita. 2006. Ekonomi Islam.Yogyakarta:mUPFE-UMY. $\mathrm{H}$ 42-43.

Daulay, Raihanah. 2016. Pengembangan Usaha Mikro Untuk Perbedayaan Ekonomi Ummat Islam di Kota Medan. Jurnal MIQOT Vol. XL No. 1 JanuariJuni. Medan: UIN Sumatra Utara. H 64.

Deliarnov. 2005. Perkembangan Pemikiran Ekonomi. Jakarta: Penerbit Rajawali Pers. H 58.

Hubeis, Musa. 2009. Prospek Usaha Kecil Dalam Wadah Inkubator Bisnis, Cet.I. Bogor: Galia Indonesia. H 18.

Kara, Muslimin. 2013. Kontribusi Pembiayaan Perbankan Syariah
Terhadap Pengembangan Usaha Mikro, Kecil, dan Menengah. Jurnal Asy-Syir'ah Jurnal Ilmu Syariah dan Hukum Vol. 47. No 1. Yogyakarta: Fakultas Syariah dan Hukum Universitas Islam Negeri Sunan Kalijaga. H 300.

Kholis, Nur. 2008. Modul Mata Kuliah Manajemen Perbankan Syariah. Yogyakarta: Prodi Ekonomi Islam Fakultas Agama Islam Universitas Islam Indonesia. H 86.

Majalah Sharing edisi Maret 2009. H 40.

Maryati, Sri. 2014. Peran Bank Pembiayaan Syariah Dalam Pengembangan UMKM dan Agrisbisnis Pedesaan di Sumatra Barat. Jurnal Economica. Vol. 3.No.1 Padang: Prodi Pendidikan Ekonomi STKIP PGRI Padang. H 15.

Muhamad. 2014. Manajemen Keuangan Syariah Analisis Fiqih dan Keuangan. Yogyakarta: UPP STIM YKPN. H 230.

Muhamad. 2009. Lembaga Keuangan Mikro Syariah Pergulatan Melawan Kemiskinan dan Penetrasi Ekonomi Global. Yogyakarta: Graha Ilmu. H 54.

Munrokhim, Misanan, dkk (P3EI UII). 2008. Ekonomi Islam. Jakarta: Penerbit Rajawali Pers. H 67-68.

Nur, Binti Aisyah. 2014. Manajemen Pembiayaan Bank Syariah. Yogyakarta: Teras. H 2-3.

Otoritas Jasa Keuangan. 2018. Statistik Perbankan Syariah Juni 2018.

Pramana, Debby dan Rachma Indrarini. 2017. Pembiayaan BPR Syariah Dalam Peningkatan Kesejahteraan UMKM Berdasarkan Maqashid Syariah. Jurnal Ekonomi dan Bisnis Islam, Vol. 3, No. 1, Januari-Juni. Surabaya: Universitas Airlangga. H 59.

Prawirokusumo, Soeharto. 2000. Kewirausahaan Dan Manajemen 
Usaha Kecil. Yogyakarta: BPFE Yogyakarta. H 48.

Qardhawi, Yusuf. 1997. Norma dan Etika Ekonomi Islam. Yogyakarta: Penerbit Gema Insani Press. H 111.

Remy, Sutan Sjahdaeni. 2014. Perbankan Syariah Produk-produk dan Aspekaspek Hukumnya. Jakarta: Kencana. $\mathrm{H}$ 176.

Sholahuddin. 2007. Asas-Asas Ekonomi Islam. Jakarta: Penerbit Rajawali Press. H 5.

Sumitro, Warkum. 2004. Azas-azas Perbankan Islam dan Lembagalembaga Terkait. Jakarta: Raja Grafindo Persada. H 168.

Telaah Terhadap Akar Krisis Keuangan Global-Bubble Economy dan Fenomena Ribawi. http://agustianto.niriah.com

Undang-Undang Nomor 20 Tahun 2008 Tentang Usaha Mikro Kecil dan Menengah.

http://www.bi.go.id/web/id/Perbankan/Perb ankan+Syariah/ Pada tanggal 18 pebruari 2011.

http://www.kemenkeu.go.id/Kajian/strategipemberdayaan-umkm-menghadapipasar-bebas-asean. Pada tanggal 29 Juni 2016.

http://www.bankmuamalat.co.id/berita/detai l/bank-syariah-lebih-melirikumkm\#.VscVSE-FrIV pada tanggal 19 Pebruari 2016.

http://pusat.baznas.go.id/poskoaceh/pembinaan-mental-dan-agamasyarat-memperbaiki-ekonomi/ pada tanggal 19 November 2017.

http://mysharing.co/pemberdayaan-umkmala-dompet-dhuafa/ pada tanggal 19 November 2017. https://ekonomi.kompas.com/read/2018/05/0 8/110200226/btpn-syariah-resmimelantai-di-bei, pada tanggal 20 Juli 2018.

https://www.republika.co.id/berita/ekonomi/ syariah-ekonomi/17/10/19/oy2ck3382btpn-syariah-sasar-nasabahpembiayaan-super-mikro, pada tanggal 21 Juli 2018

https://keuangan.kontan.co.id/news/btpnsyariah-mulai-beroperasi-21-juli2014, pada tanggal 20 Juli 2018.https://keuangan.kontan.co.id/ne ws/btpn-syariah-bukukan- 